\title{
Metastatic Urothelial Carcinoma of the Renal Pelvis and Ureter
}

National Cancer Institute

\section{Source}

National Cancer Institute. Metastatic Urothelial Carcinoma of the Renal Pelvis and Ureter. NCl Thesaurus. Code C8064.

A transitional cell carcinoma of the renal pelvis and ureter which has spread from its original site of growth to another anatomic site. 